\title{
PERBEDAAN KEMAMPUAN PENALARAN MATEMATIS SISWA YANG DIAJAR DENGAN MODEL PEMBELAJARAN DISCOVERY LEARNING DAN MODEL PEMBELAJARAN KOOPERATIF TIPE STAD DI KELAS VIII SMP NEGERI 6 MEDAN
}

\author{
Indah Syahputri; Martua Manullang \\ Prodi Pendidikan Matematika, Fakultas Matematika dan Ilmu Pengetahuan Alam, \\ Universitas Negeri Medan (UNIMED), 20221 Medan, Sumatera Utara, Indonesia \\ Email: syahputrii32@gmail.com
}

\begin{abstract}
ABSTRAK
Penelitian ini bertujuan untuk mengetahui bahwa kemampuan penalaran matematis siswa yang diajar dengan model pembelajaran Discovery Learning lebih tinggi daripada siswa yang diajar dengan model pembelajaran kooperatif tipe STAD di kelas VIII SMP Negeri 6 Medan T.A 2016/2017. Jenis penelitian ini adalah eksperimen semu. Populasi dalam penelitian ini adalah seluruh siswa kelas VIII Semester genap SMP Negeri 6 Medan dan sampel dalam penelitian ini adalah siswa kelas VIII-C dan kelas VIII-D sebanyak 76 siswa. Instrumen yang digunakan untuk mengetahui kemampuan penalaran matematis siswa adalah tes kemampuan penalaran matematis yang telah divalidasi dalam bentuk uraian. Dari hasil penelitian yang diberi perlakuan yang berbeda, kelas eksperimen 1 dengan model pembelajaran Discovery Learning dan kelas eksperimen 2 dengan model pembelajaran kooperatif tipe STAD diperoleh kesimpulan bahwa kemampuan penalaran matematis siswa yang diajar dengan model pembelajaran Discovery Learning lebih tinggi daripada siswa yang diajar dengan model pembelajaran kooperatif tipe STAD di kelas VIII SMP Negeri 6 Medan T.A. 2016/2017
\end{abstract}

Kata Kunci : Discovery Learning, STAD, Penalaran Matematis

\begin{abstract}
This study aims to determine that the students' mathematical reasoning abilities taught by the learning model of Discovery Learning is higher than the students who are taught by STAD type cooperative learning model in class VIII SMP Negeri 6 Medan T.A 2016/2017. This type of research is a quasi experiment. The population in this study is all students of class VIII Semester even Junior High School 6 Medan and the sample in this study are students of class VIII-C and class VIII-D as many as 76 students. The instrument used to determine students' mathematical reasoning abilities is a validated test of mathematical reasoning ability in the form of a description. From the results of different research, experimental class 1 with the learning model of Discovery Learning and experiment 2 class with STAD type cooperative learning model obtained the conclusion that the students' mathematical reasoning ability taught by the learning model of Discovery Learning is higher than the students who are taught by the model of learning Cooperative type STAD in class VIII SMP Negeri 6 Medan TA 2016/2017
\end{abstract}

Keywords: Discovery Learning, STAD, Mathematical Reasoning

Indah Syahputri; Martua Manullang. Perbedaan Kemampuan Penalaran Matematis Siswa yang Diajar dengan Model Pembelajaran Discovery Learning dan Model Pembelajaran Kooperatif Tipe STAD di Kelas VIII SMP Negeri 6 Medan. Jurnal Inspiratif, Vol. 3 No. 2 Agustus 2017. 


\section{Pendahuluan}

Pada umumnya, pendidikan diselenggarakan secara formal dengan beberapa jenjang, diantaranya adalah pendidikan menengah. Dalam pendidikan formal tersebut, matematika merupakan mata pelajaran wajib yang dipelajari pada setiap jenjang. Matematika merupakan salah satu mata pelajaran yang memiliki peranan penting dalam pengembangan kemampuan berpikir siswa. Selain itu, pembelajaran matematika menurut standar isi untuk satuan pendidikan dasar dan menengah (BSPN, 2006: 140) bertujuan agar peserta didik memiliki kemampuan sebagai berikut:

1. Memahami konsep matematika, menjelaskan keterkaitan antar konsep dan mengaplikasikan konsep atau algoritma secara luwes, akurat, efisien, dan tepat, dalam pemecahan masalah.

2. Menggunakan penalaran pada pola dan sifat, melakukan manipulasi matematika dalam membuat generalisasi, menyusun bukti, atau menjelaskan gagasan dan pernyataan matematika.

3. Memecahkan masalah yang meliputi kemampuan memahami masalah, merancang model matematika, menyelesaikan model dan menafsirkan solusi yang diperoleh.

4. Mengkomunikasikan gagasan dengan simbol, tabel, diagram, atau media lain untuk memperjelas keadaan atau masalah.

5. Memiliki sikap menghargai kegunaan matematika dalam kehidupan, yaitu memiliki rasa ingin tahu, perhatian, dan minat dalam mempelajari matematika, serta sikap ulet dan percaya diri dalam pemecahan masalah.

Dari pernyataan tersebut dapat diketahui bahwa terdapat lima kemampuan dasar dalam pembelajaran matematika yaitu kemampuan pemahaman konsep, kemampuan penalaran, kemampuan pemecahan masalah, kemampuan komukasi matematika, dan representasi.

Salah satu kemampuan dasar dalam mempelajari matematika yaitu penalaran. Penalaran merupakan salah satu proses berpikir melalui beberapa fakta atau prinsip menuju suatu kesimpulan dan sangat erat kaitannya dengan materi matematika. Menurut Shadiq (2004: 2), "Penalaran adalah suatu kegiatan, suatu proses, atau suatu aktivitas berpikir untuk menarik kesimpulan atau membuat suatu pernyataan baru yang benar berdasar pada beberapa pernyataan yang kebenarannya telah dibuktikan atau diasumsikan sebelumnya." Matematika dan penalaran sendiri merupakan hal yang terkait. Depdiknas (2002: 6) menjelaskan bahwa, "Materi matematika dan penalaran matematika merupakan dua hal yang tidak dapat dipisahkan, yaitu materi matematika dipahami melalui penalaran dan penalaran dipahami dan dilatihkan melalui belajar materi matematika." Selain merupakan tujuan utama pembelajaran matematika, kemampuan atau keterampilan bernalar ini juga akan bermanfaat untuk ilmu lain selain matematika, serta akan bermanfaat untuk kehidupan sehari-hari siswa. Setiap manusia harus mampu bernalar secara baik untuk dapat memecahkan masalah ataupun menentukan keputusan.

Menurut Lestari (2016: 2), "Siswa pada tingkat sekolah menengah harus memiliki kemampuan penalaran matematis." Lebih lanjut, berdasarkan hasil analisis pada studi TIMSS dan PIRLS (dalam Hasratuddin, 2015: 9394) menunjukkan bahwa soal-soal yang digunakan untuk mengukur kemampuan peserta didik dibagi menjadi empat kategori, yaitu: (1) Low; mengukur kemampuan sampai level knowing, (2) Intermediate; mengukur kemampuan sampai level applying, (3) High; mengukur kemampuan sampai level reasoning, (4) Advanced; mengukur

Indah Syahputri; Martua Manullang. Perbedaan Kemampuan Penalaran Matematis Siswa yang Diajar dengan Model Pembelajaran Discovery Learning dan Model Pembelajaran Kooperatif Tipe STAD di Kelas VIII SMP Negeri 6 Medan. Jurnal Inspiratif, Vol. 3 No. 2 Agustus 2017. 
kemampuan sampai level reasoning with incomplete information. Dari kategori kemampuan tersebut artinya penalaran sangat diperlukan dalam menumbuhkan rasa percaya diri dan tanggung jawab dalam melakukan suatu pekerjaan.

$$
\text { Pada kenyataanya }
$$

kemampuan penalaran matematis siswa masih rendah, padahal pembelajaran matematika mendapat bagian yang cukup besar dibanding jam pelajaran lain. Banyak kelemahan kemampuan matematika siswa Indonesia yang terungkap pada hasil studi PISA dan TIMSS. Wardhani dan Rumiati (2011: 59) menjelaskan bahwa secara umum kelemahan siswa adalah belum mampu mengembangkan kemampuan bernalarnya, belum mempunyai kebiasaan membaca sambil berpikir dan bekerja agar dapat memahami informasi dan strategis dalam menyelesaikan soal, dan masih cenderung menerima informasi kemudian melupakannya, sehingga mata pelajaran matematika belum menjadi sekolah berpikir bagi siswa. Kemampuan penalaran siswa dipengaruhi oleh banyak hal, diantaranya adalah penggunaan model pembelajaran yang tepat, pembelajaran yang berpusat pada siswa, dan interaksi yang terjadi tidak hanya antara guru dengan siswa tetapi juga antara siswa dengan siswa. Namun kegiatan belajar mengajar yang terjadi masih dengan model pembelajaran yang didominasi oleh pembelajaran yang berpusat pada guru. Guru secara monoton menguasai kelas sehingga siswa tidak terlibat secara aktif dalam proses pembelajaran dan kurang leluasa dalam menyampaikan ide serta gagasannya.

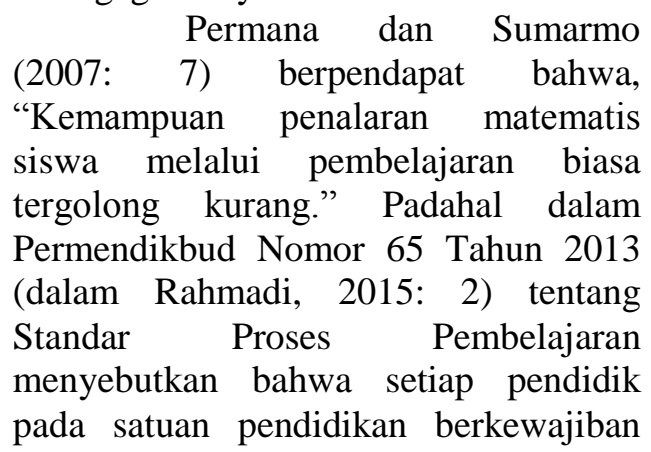

menyusun perangkat pembelajaran secara lengkap dan sistematis agar pembelajaran berlangsung secara interaktif, inspiratif, menyenangkan, memotivasi peserta didik untuk aktif, serta memberikan ruang lingkup kreatif dan mandiri sesuai dengan bakat, minat dan potensi yang dimiliki peserta didik. Pemilihan model pembelajaran yang tepat dapat memberikan kesempatan kepada siswa untuk dapat mengembangkan kemampuan secara optimal. Penggunaan model pembelajaran yang tidak sesuai akan mengakibatkan proses pembelajaran tidak optimal, sehingga tujuan dari pembelajaran itu sendiri tidak akan tercapai. Peningkatan kualitas pendidikan tidak terlepas dari usahausaha pendidik untuk menerapkan model-model pembelajaran yang dapat memotivasi siswa untuk lebih efektif belajar.

Model pembelajaran
Discovery Learning dapat dijadikan alternatif yang diharapkan yang dapat membuat siswa aktif dan bermakna dalam belajar matematika. Discovery Learning (penemuan) berupaya menanamkan dasar-dasar berpikir ilmiah pada diri siswa sehingga dalam proses pembelajaran siswa lebih banyak belajar sendiri, mengembangkan kreativitas dalam memecahkan masalah. Siswa benar-benar ditempatkan sebagai subjek yang belajar. Peranan guru dalam pembelajaran dengan metode penemuan adalah sebagai pembimbing dan fasilitator. Purnandita (2015: 4) menjelaskan bahwa, "Pengetahuan yang diperoleh dari model pembelajaran Discovery Learning menunjukkan beberapa kebaikan sebagai berikut: 1) Pengetahuan itu bertahan lama atau lebih mudah diingat; 2) Hasil belajar mempunyai efek transfer yang lebih baik; 3) Meningkatkan penalaran siswa dan kemampuan untuk berpikir." Discovery learning menuntut siswa belajar lebih aktif, berfikir analisis dan mencoba memecahkan problem yang dihadapi sendiri, yang ditransfer dalam

Indah Syahputri; Martua Manullang. Perbedaan Kemampuan Penalaran Matematis Siswa yang Diajar dengan Model Pembelajaran Discovery Learning dan Model Pembelajaran Kooperatif Tipe STAD di Kelas VIII SMP Negeri 6 Medan. Jurnal Inspiratif, Vol. 3 No. 2 Agustus 2017. 
kehidupan bermasyarakat dan diharapkan mampu meningkatkan hasil belajar kognitif siswa. Discovery Learning merupakan pembelajaran yang mengutamakan cara belajar aktif, berorientasi pada proses, mengarahkan sendiri dan reflektif. Keadaan ini memungkinkan siswa untuk mengembangkan kemampuan penalarannya melalui cara belajar aktif dan penemuan sendiri yang dilakukan oleh siswa.

Model pembelajaran lain yang dapat melatih kemampuan penalaran siswa adalah model pembelajaran kooperatif, salah satunya adalah Student Teams Achievement Divisions (STAD). Pembelajaran kooperatif tipe STAD merupakan tipe sederhana dimana siswa belajar dalam kelompok-kelompok kecil yang terdiri dari 4-5 orang anggota yang saling membantu satu sama lain dan merupakan campuran tingkat kemampuan, jenis kelamin dan suku. Pembelajaran kooperatif tipe STAD merupakan model pembelajaran yang cocok diterapkan dalam kelas yang memiliki karakteristik yang heterogen, baik dalam kemampuan akademis, jenis kelamin, suku, motivasi, dan lain-lain. Dalam pembelajaran kooperatif tipe STAD ini tanggung jawab siswa terhadap proses belajar lebih besar karena siswa lebih banyak bekerja daripada sekedar mendengarkan informasi sehingga metode pembelajaran ini dapat melatih tanggung jawab siswa terhadap proses belajarnya.

Pembelajaran kooperatif STAD menekankan pada pemberian penghargaan sebagai bentuk reinforcement, sehingga dapat digunakan untuk meningkatkan semangat belajar siswa yang akhirnya dapat meningkatkan hasil belajar siswa. Dalam STAD semua siswa mempunyai kesempatan yang sama untuk meraih keberhasilan, karena semua anggota kelompok mempunyai kesempatan mengkontribusikan nilai pada kelompok sebagai hasil peningkatan kemampuan dari waktu sebelumnya. Hal ini berarti gagasan utama dari STAD adalah untuk memotivasi siswa supaya saling mendukung dan membantu satu sama lain di dalam kelompoknya untuk mencapai satu penghargaan bersama. Dengan adanya penghargaan yang ingin dicapai tersebut secara tidak langsung akan memberikan dorongan dan motivasi lebih terhadap setiap anggota kelompok untuk lebih aktif dalam proses belajar dan berupaya lebih keras menyelesaikan suatu masalah yang diberikan. Pada umumnya penghargaan tidak diberikan begitu saja, untuk mendapatkan suatu penghargaan setiap individu haruslah berusaha keras memperoleh keberhasilan dengan menyelesaikan masalah yang diberikan. Hal ini berarti dengan adanya pemberian penghargaan terhadap keberhasilan kelompok akan menjadi daya tarik dan motivasi terhadap siswa agar lebih aktif dalam kelompoknya untuk sama-sama berupaya lebih keras dalam mengembangkan kemampuan penalaran yaitu siswa dapat melakukan analisis terhadap informasi dan fakta-fakta yang ada untuk menghasilkan kesimpulan. Terkait model pembelajaran kooperatif tipe STAD dalam mengembangkan kemampuan penalaran matematis Muharom (2014) menyatakan bahwa, kemampuan penalaran matematis siswa yang mengikuti pembelajaran kooperatif tipe Student Teams Achievement Division (STAD) lebih baik daripada peserta didik yang mengikuti pembelajaran langsung.

\section{Metode Penelitian}

Penelitian ini merupakan penelitian eksperimen semu karena kondisi siswa tidak dapat dikontrol sepenuhnya seperti: persiapan siswa sebelum mengajar, les tambahan di luar jam sekolah, hubungan siswa dengan orang tua, hubungan siswa dengan lingkungannya, dan lain sebagainya. Penelitian ini melibatkan dua kelas sampel yang dipilih dengan teknik

Indah Syahputri; Martua Manullang. Perbedaan Kemampuan Penalaran Matematis Siswa yang Diajar dengan Model Pembelajaran Discovery Learning dan Model Pembelajaran Kooperatif Tipe STAD di Kelas VIII SMP Negeri 6 Medan. Jurnal Inspiratif, Vol. 3 No. 2 Agustus 2017. 
cluster sampling dengan dua perlakuan yang berbeda antara kelas eksperimen 1 (VIII-C) dan kelas eksperimen 2 (VIIID). Pada kelas eksperimen 1, proses pembelajaran dilaksanakan dengan model pembelajaran Discovery Learning, sedangkan pada kelas eksperimen 2 proses pembelajaran dilaksanakan dengan model pembelajaran kooperatif tipe Student Teams Achievement Divisions (STAD).

\section{Hasil Penelitian}

\section{A. Deskripsi Hasil Penelitian}

Penelitian yang dilakukan di kelas VIII SMP Negeri 6 Medan ini menerapkan pembelajaran yang berbeda. Kelas eksperimen 1 menggunakan model pembelajaran Discovery Learning dan kelas eksperimen 2 menggunakan model pembelajaran kooperatif tipe
Student Teams Achievement Divisions (STAD). Dalam penelitian ini data yang akan diolah adalah selisih antara nilai posttest dan pretest siswa.

\section{B. Analisis Hasil Penelitian}

1. Uji Normalitas

Uji normalitas dilakukan untuk mengetahui apakah sampel data berasal dari populasi berdistribusi normal atau tidak. Untuk mengetahui sebaran data berdistribusi normal atau tidak dapat dilakukan uji normalitas dengan menggunakan uji Chi-Kuadrat dengan syarat normal yang harus dipenuhi adalah $\chi_{\text {hitung }}^{2}<\chi^{2}(1-\alpha)(k-1)$ pada taraf nyata $\alpha=0,05$. Secara ringkas hasil pehitungan uji normalitas data selisih posttest-pretest dapat dilihat pada tabel berikut:

Tabel 1. Ringkasan Uji Normalitas Data

\begin{tabular}{|l|c|c|c|c|c|}
\hline \multicolumn{1}{|c|}{ Data } & Kelas & $\mathrm{N}$ & $\chi^{2}$ hitung & $\chi^{2}{ }_{\text {tabel }}$ & Kesimpulan \\
\hline $\begin{array}{l}\text { Selisih Posttest- } \\
\text { Pretest }\end{array}$ & Eksperimen 1 & 38 & 1,780 & 11,07 & Berdistribusi Normal \\
\cline { 2 - 6 } & Eksperimen 2 & 38 & 10,159 & 11,07 & Berdistribusi Normal \\
\hline
\end{tabular}

Dari tabel tersebut menunjukan bahwa data selisih posttest-pretest siswa kedua kelompok sampel dinyatakan berdistribusi normal dengan harga $\chi_{\text {hitung }}^{2}<\chi_{\text {tabel }}^{2}$.

\section{Uji Homogenitas}

Pengujian homogenitas data dilakukan untuk mengetahui apakah kelompok sampel yang digunakan dalam penelitian ini berasal dari populasi yang homogen atau tidak, artinya apakah sampel yang digunakan dapat mewakili seluruh populasi yang ada. Hasil perhitungan uji homogenitas data dengan menggunakan uji F. Jika $F_{\text {hitung }} \geq$ $\mathrm{F}_{\text {tabel }}$ maka $\mathrm{H}_{0}$ ditolak atau kedua varians berbeda. Sedangkan jika $F_{\text {hitung }}<F_{\text {tabel }}$ maka $\mathrm{H}_{0}$ diterima atau kedua varians sama. Dengan derajat kebebasan pembilang $=\left(\mathrm{n}_{1}-1\right)$ dan derajat kebebasan penyebut $=\left(\mathrm{n}_{2}-1\right)$ dengan taraf nyata $\alpha=0,05$. Ringkasan hasil uji homogenitas disajikan pada tabel berikut:

Tabel 2. Ringkasan Perhitungan Uji Homogenitas Data

\begin{tabular}{|c|l|l|c|}
\hline Kelas & $\mathrm{F}_{\text {hitung }}$ & $\mathrm{F}_{\text {tabel }}$ & Kesimpulan \\
\hline Selisih Posttest-Pretest & 1,732 & 1,771 & Homogen \\
\hline
\end{tabular}

Berdasarkan tabel di atas diperoleh $\mathrm{F}_{\text {hitung }}<\mathrm{F}_{\text {tabel }}$ maka data selisih posttest- pretest siswa dinyatakan memiliki varians yang sama atau homogen. 
Setelah dilakukan uji normalitas diketahui bahwa sampel kedua kelas sampel berdistribusi normal dan memiliki varians yang homogen maka dilakukan pengujian hipotesis menggunakan uji kesamaan rata-rata (uji t satu pihak).

Hipotesis yang diuji adalah:

$$
\begin{aligned}
& H_{0}: \mu_{1} \leq \mu_{2} \\
& H_{a}: \mu_{1}>\mu_{2} \\
& \text { dimana }
\end{aligned}
$$

$\mu_{1}$ : rata-rata kemampuan penalaran matematis siswa yang diajar dengan menggunakan model pembelajaran Discovery Learning.

$\mu_{2}$ : rata-rata kemampuan penalaran matematis siswa ayang diajar dengan menggunakan model pembelajaran kooperatif tipe Student Teams Achievement Divisions (STAD).

Secara ringkas hasil perhitungan uji hipotesis dapat dilihat dalam tabel berikut

Tabel 3. Ringkasan Perhitungan Uji Hipotesis Data Selisih Posttest-Pretest

\begin{tabular}{|c|l|c|c|c|c|}
\hline & Data Kelas & $\begin{array}{c}\text { Nilai } \\
\text { Rata-rata }\end{array}$ & $\mathrm{t}_{\text {hitung }}$ & $\mathrm{t}_{\text {tabel }}$ & Kesimpulan \\
\hline \multirow{2}{*}{ Uji-t sepihak } & Eksperimen 1 & 12,316 & 3,685 & 1,66571 & Terima $\mathrm{H}_{\mathrm{a}}$ \\
\cline { 2 - 6 } & Eksperimen 2 & 8,657 & & & \\
\hline
\end{tabular}

Berdasarkan tabel diatas hasil pengujian pada taraf signifikansi $\alpha=0,05 \mathrm{dan} \mathrm{dk}=$ $\mathrm{n}_{1}+\mathrm{n}_{2}-2=74$ dengan $\mathrm{t}_{\text {hitung }}=3,685$ dan $\mathrm{t}_{\text {tabel }}=1,66571$ sehingga terlihat $t_{\text {hitung }}>t_{\text {tabel }}$ yaitu $3,685>1,66571$ yang berarti bahwa $\mathrm{H}_{\mathrm{o}}$ ditolak dan $\mathrm{H}_{\mathrm{a}}$ diterima. Sehingga disimpulkan bahwa kemampuan penalaran matematis siswa Pembahasan

Penelitian yang dilakukan di SMP Negeri 6 Medan ini digunakan dua model pembelajaran yang berbeda yaitu kelas eksperimen 1 menggunakan model pembelajaran Discovery Learning dan kelas eksperimen 2 menggunakan model pembelajaran kooperatif tipe Student Teams Achievement Divisions (STAD). Kelas eksperimen 1 terdiri dari 38 siswa dan kelas eksperimen 2 terdiri dari 38 siswa. Sebelum diberikan pembelajaran yang berbeda pada kedua kelas eksperimen, terlebih dahulu dilakukan pretest untuk mengetahui kemampuan awal siswa. Dari hasil pretest diperoleh rata-rata skor siswa pada kelas eksperimen 1 yaitu 14,5526 dan kelas eksperimen 2 yaitu 13,8157. Rata-rata kemampuan penalaran matematis siswa tergolong dalam kriteria rendah. Berdasarkan hasil pretest kedua kelas eksperimen dilakukan uji normalitas dan yang diajar dengan menggunakan model pembelajaran Discovery Learning lebih tinggi daripada kemampuan penalaran matematis siswa yang diajar dengan menggunakan model pembelajaran kooperatif tipe STAD.

homogenitas, diperoleh hasil bahwa kedua kelas berdistribusi normal, homogen, dan kemampuan awal kedua kelas tidak berbeda jauh.

$$
\text { Setelah diketahui }
$$

kemampuan awal siswa, maka diberikan pembelajaran yang berbeda kepada kedua kelas eksperimen. Kelas eksperimen 1 menggunakan model pembelajaran Discovery Learning dan kelas eksperimen 2 menggunakan model pembelajaran kooperatif tipe Student Teams Achievement Divisions (STAD).

Perbedaan model pembelajaran Discovery Learning dan model pembelajaran kooperatif tipe STAD yang paling mendasar yaitu pada pembelajaran Discovery Learning dalam proses pembelajarannya menanamkan dasar-dasar berpikir ilmiah pada diri siswa sehingga dalam proses pembelajaran siswa lebih banyak belajar sendiri, mengembangkan kreativitas dalam memecahkan masalah. Discovery

Indah Syahputri; Martua Manullang. Perbedaan Kemampuan Penalaran Matematis Siswa yang Diajar dengan Model Pembelajaran Discovery Learning dan Model Pembelajaran Kooperatif Tipe STAD di Kelas VIII SMP Negeri 6 Medan. Jurnal Inspiratif, Vol. 3 No. 2 Agustus 2017. 
Learning merupakan pembelajaran yang mengutamakan cara belajar aktif, berorientasi pada proses, mengarahkan sendiri dan reflektif. Sedangkan pembelajaran kooperatif tipe STAD menekankan pada pemberian penghargaan sebagai bentuk reinforcement, sehingga dapat digunakan untuk meningkatkan semangat belajar siswa yang akhirnya dapat meningkatkan hasil belajar siswa. Dengan adanya penghargaan yang ingin dicapai tersebut secara tidak langsung akan memberikan dorongan dan motivasi lebih terhadap setiap anggota kelompok untuk lebih aktif dalam proses belajar dan berupaya lebih keras menyelesaikan suatu masalah yang diberikan.

Pada akhir pembelajaran mengetahui bagaimana penalaran matematis siswa kedua kelas setelah diberikan perlakuan yang berbeda. Dari hasil penelitian diperoleh bahwa ratarata skor kelas eksperimen 1 yang menggunakan pembelajaran Discovery Learning adalah 26,7631, sedangkan rata-rata skor siswa kelas eksperimen 2 yang menggunakan pembelajaran kooperatif tipe STAD sebesar 22,7631.

Dari data posttest dan pretest diperoleh rata-rata selisih posttestpretest kelas eksperimen 1 sebesar 12,316 dan kelas eksperimen 2 sebesar 8,657 . Kemudian dilakukan pengujian normalitas dan homogenitas, diperoleh bahwa data kedua kelas kelas berdistribusi normal dan homogen. Artinya bahwa kedua kelas dapat mewakili seluruh populasi di kelas VIII SMP Negeri 6 Medan. Selanjutnya dilakukan pengujian hipotesis untuk kemampuan penalaran matematis siswa dengan menggunakan uji-t sepihak. Setelah dilakukan pengujian data, ternyata diperoleh hasil pengujian kemampuan penalaran matematis pada taraf signifikansi $\alpha=0,05, t_{\text {hitung }}>$ $t_{\text {tabel }}$ yaitu $3,685>1,66571$, maka $\mathrm{H}_{\mathrm{o}}$ ditolak dan $\mathrm{H}_{\mathrm{a}}$ diterima. Dengan demikian dapat disimpulkan bahwa penalaran matematis siswa yang diajar dengan model pembelajaran Discovery Learning lebih tinggi daripada siswa yang diajar dengan model pembelajaran kooperatif tipe STAD. Hal ini juga sejalan dengan pendapat Purnandita (2015: 4) menjelaskan bahwa, "Pengetahuan yang diperoleh dari model pembelajaran Discovery Learning menunjukkan beberapa kebaikan sebagai berikut: 1) Pengetahuan itu bertahan lama atau lebih mudah diingat; 2) Hasil belajar mempunyai efek transfer yang lebih baik; 3) Meningkatkan penalaran siswa dan kemampuan untuk berpikir."

Untuk memperkuat hasil penelitian ini, peneliti membandingkan hasil penelitian yang diperoleh dengan hasil penelitian terdahulu yang relevan dengan penelitian ini. Berikut disajikan hasil penelitian terdahulu yang relevan dengan penelitian ini yaitu penelitian yang dilakukan oleh Nur Choiro Siregar dan Marsigit (2015) menjelaskan hasil perhitungan yang dilakukan menghasilkan $\mathrm{t}=3,182$. Sedangkan untuk $\mathrm{t}$ tabel $=1,995$. Karena nilai $\mathrm{t}$ hitung > t-tabel maka dapat disimpulkan bahwa pembelajaran matematika dengan pendekatan discovery lebih unggul daripada pendekatan konvensional ditinjau dari kemampuan penalaran. Sulistiawati (2104) menjelaskan bahwa siswa baik siswa SMP masih memiliki kesulitan dalam mengerjakan soal-soal penalaran matematis. Rata-rata kesulitan yang dialami siswa dalam mengerjakan soal-soal yang diberikan untuk tingkat SMP sebesar $85,71 \%$. Persentase kesulitan belajar yang muncul ternyata masih cukup besar. Oleh karena itu disimpulkan bahwa siswa masih memiliki kesulitan belajar dalam kemampuan penalaran matematis. Untuk mengatasi kesulitan-kesulitan yang dialami oleh siswa kiranya perlu dikembangkan metode/strategi/model pembelajaran atau bahan ajar yang dapat mengatasi kesulitan-kesulitan dalam geometri.

Puput Suriyah, dkk (2015) menyimpulkan bahwa penerapan model

Indah Syahputri; Martua Manullang. Perbedaan Kemampuan Penalaran Matematis Siswa yang Diajar dengan Model Pembelajaran Discovery Learning dan Model Pembelajaran Kooperatif Tipe STAD di Kelas VIII SMP Negeri 6 Medan. Jurnal Inspiratif, Vol. 3 No. 2 Agustus 2017. 
pembelajaran Discovery Learning memiliki prestasi belajar matematika yang lebih baik dari pada siswa yang diajar menggunakan model pembelajaran Student Teams Achievement Divisions (STAD) dan pembelajaran langsung. Berdasarkan hasil tes prestasi belajar matematika diperoleh rata-rata nilai dalam pembelajaran Discovery Learning sebesar 72,8539, dalam pembelajaran kooperatif tipe STAD diperoleh rata-rata nilai sebesar 63,2727, dan dengan pembelajaran langsung diperoleh ratarata nilai sebesar 54,3636. Dari hasil penelitian yang relevan diatas. dapat disimpulkan bahwa pembelajaran Discovery Learning merupakan variabel penting dalam meningkatkan penalaran matematis siswa.

Dalam penelitian ini diperoleh bahwa nilai rata-rata tes kemampuan penalaran matematis dalam pembelajaran Discovery Learning sebesar 60,825 dan nilai rata-rata tes kemampuan penalaran matematis dalam pembelajaran kooperatif tipe STAD sebesar 51,734 jika jika dibandingkan dengan beberapa penelitian yang relevan tersebut maka nilai tes siswa pada penelitian ini memiliki hasil yang lebih rendah. Tetapi nilai tes untuk kelas eksperimen 1 (pembelajaran Discovery Learning) dan kelas eksperimen 2 (pembelajaran kooperatif tipe STAD) tidak berbeda jauh secara signifikan. Untuk nilai selisih posttest-pretest tes kemampuan penalaran matematis kelas eksperimen 1 mempunyai rata-rata peningkatan nilai sebesar 27,990 dan kelas eksperimen 2 mempunyai rata-rata peningkatan nilai sebesar 19,677.

Adapun kekurangan dalam penelitian ini dibandingkan dengan beberapa peneltian relevan tersebut adalah adanya beberapa siswa yang kurang bersungguh-sungguh menanggapi permasalahan yang diberikan ketika mereka diminta untuk memikirkan permasalahan tersebut. Kemudian kurangnya waktu yang tersedia untuk mendiskusikan permasalahan yang diberikan kepada siswa serta menyampaikan hasil diskusi tersebut di depan kelas. Selain itu pada saat peneliti mendemonstrasikan materi pelajaran beberapa siswa ada yang tidak memahami pelajaran tetapi malu untuk bertanya sehingga pada saat diskusi siswa tersebut mendiskusikan hal-hal yang tidak berkaitan tentang materi pelajaran sehingga berdampak kepada hasil belajarnya. Adapun kelebihan dari penelitian ini dibandingkan dengan penelitian relevan di atas siswa adalah sebagian besar siswa lebih aktif bertanya maupun mengeluarkan pendapat dalam diskusi kelompok. Berdasarkan penelitian menunjukkan bahwa pengajaran materi kubus dan balok dengan model pembelajaran Discovery Learning lebih mudah dipahami siswa dibandingkan dengan model pembelajaran kooperatif tipe STAD.

\section{SIMPULAN}

Berdasarkan hasil penelitian maka dapat disimpulkan bahwa kemampuan penalaran matematis siswa yang diajar dengan model pembelajaran Discovery Learning lebih tinggi daripada siswa yang diajar dengan model pembelajaran kooperatif tipe Student Teams Achievement Divisions (STAD) di kelas VIII SMP Negeri 6 Medan.

\section{SARAN}

1. Kepada guru khususnya guru matematika agar menggunakan model pembelajaran Discovery Learning sebagai salah satu alternative pembelajaran dalam upaya mengaktifkan siswa dalam kemampuan penalaran matematis yang lebih baik.

2. Bagi guru-guru atau calon guru yang akan menerapkan model pembelajaran Discovery Learning sebaiknya terlebih dahulu mengarahkan siswa untuk membaca langkah-langkah pada lembar kegiatan siswa dan memperhatikan alokasi waktu yang ada secara

Indah Syahputri; Martua Manullang. Perbedaan Kemampuan Penalaran Matematis Siswa yang Diajar dengan Model Pembelajaran Discovery Learning dan Model Pembelajaran Kooperatif Tipe STAD di Kelas VIII SMP Negeri 6 Medan. Jurnal Inspiratif, Vol. 3 No. 2 Agustus 2017. 
cermat sehingga pembelajaran dapat berjalan sesuai dengan yang diharapkan.

3. Bagi peneliti lanjutan, hendaknya penelitian dapat dilengkapi dengan meneliti aspek lain secara terperinci yang belum terjangkau dalam penelitian ini.

\section{DAFTAR PUSTAKA}

BSNP, (2006), Permendiknas No.22 Tahun 2006 tentang Standar Isi untuk Satuan Pendidikan Dasar dan Menengah, Depdiknas, Jakarta.

Depdiknas, (2002), Ringkasan Kegiatan Belajar Mengajar, Depdiknas, Jakarta.

Hasratuddin, (2015), Mengapa Harus Belajar Matematika?, Perdana Publishing, Medan.

Lestari, Indah, (2016), Peningkatan Kemampuan Penalaran Matematis Siswa Menggunakan Pendekatan Matematika Realistik, Jurnal Inovasi Pendidikan Dasar, ISSN: 2477-3581.

Muharom, Tria, (2014), Pengaruh Pembelajaran Dengan Model Kooperatif Tipe Student Teams Achievement Division (STAD) Terhadap Kemampuan Penalaran dan Komunikasi Matematik Peserta Didik di SMK Negeri Manonjaya Kabupaten Tasikmalaya, Jurnal Pendidikan dan Keguruan, Vol 1 No. 1, 2014, artikel 1.

Nur Choiro Siregar dan Marsigit (2015), Pengaruh Pendekatan Discovery Learning yang Menekankan Aspek Analogi Terhadap Prestasi Belajar, Kemampuan Penalaran,
Kecerdasan Emosional Spritual, Jurnal Riset Pendidikan Matematika, Vol. 2 No. 2. ISSN: 2356-2684.

Permana, Yanto dan Utari Sumarmo, (2007), Mengembangkan Kemampuan Penalaran dan Koneksi Matematis Siswa SMA Melalui Pembelajaran Berbasis Masalah, Jurnal Educationist, ISSN: 19078838.

Puput Suriyah, dkk, (2015), Eksperimentasi Model Pembelajaran Kooperatif STAD With Guided Discovery Learning Pada Materi Pokok Lingkaran Ditinjau Dari Adversity Quotient (AQ), Jurnal Elektronik Pembelajaran Matematika, Vol. 3 No. 3, ISSN-2339-1685.

Purnandita, Fajar, (2015), Komparasi Model Pembelajaran Discovery Learning Dengan Student Team Achievement Division (STAD) Terhadap Hasil Belajar Kognitif Ilmu Bangunan Gedung Siswa Kelas X SMK N 1 Kendal, Jurnal Pendidikan dan Keguruan, Vol. 2 No. 1, 2015.

\begin{tabular}{lr} 
Rahmadi, & \multicolumn{1}{c}{ Furdan, } \\
Pengembangan & Perangkat \\
Pembelajaran & Berbasis \\
Pemecahan & Masalah \\
Berorientasi & Pada \\
Kemampuan & Penalaran dan \\
Komunikasi & Matematika, \\
Jurnal & Pendidikan \\
Matematika, Vol.10 No.2, & No. \\
ISSN: 1978-4538.
\end{tabular}

Shadiq, Fadjar, (2004), Pemecahan Masalah, Penalaran, dan Komunikasi, Disampaikan

Indah Syahputri; Martua Manullang. Perbedaan Kemampuan Penalaran Matematis Siswa yang Diajar dengan Model Pembelajaran Discovery Learning dan Model Pembelajaran Kooperatif Tipe STAD di Kelas VIII SMP Negeri 6 Medan. Jurnal Inspiratif, Vol. 3 No. 2 Agustus 2017. 


pada Diklat Instruktur/
Pengembang Matematika
SMA Jenjang Dasar,
Yogyakarta.

Sulistiawati, (2014), Analisis Kesulitan Belajar Kemampuan Penalaran Matematis Siswa SMP Pada Materi Luas Permukaan dan Volume Limas, Proceding Seminar

\author{
Nasional Pendidikan \\ Matematika, Sains, dan TIK \\ STKIP Surya, ISBN-978- \\ 602-14432-2-4.
}

Wardhani, Sri dan Rumiati, (2011), Instrumen Penilaian Hasil BelajarMatematika SMP: Belajar dari PISA dan TIMSS, Kemdiknas P4TK Matematika, Yogyakarta. 